\title{
UTILISATION OF CFBC FLY ASH IN HARDENING SLURRIES FOR FLOOD-PROTECTING DIKES
}

\author{
Z. KLEDYŃSKI ${ }^{1}$, P. FALACIŃSKI ${ }^{2}$, A. MACHOWSKA ${ }^{3}$, \\ J. DYCZEK ${ }^{4}$, L. KOTWICA ${ }^{5}$
}

\begin{abstract}
Strength and permeability properties along with microstructural evolution of hardened slurries composed of fly ash from fluidal bed combustion of brown coal and an addition of OPC/BFSC is assessed in this paper. An increase in the amount of fly ash in slurries influences the development of mechanical strength and a decrease of hydraulic conductivity. SEM, XRD, and porosity analyses confirmed formation of watertight microstructures. The structure of slurries is composed of ettringite, C-S-H phase, AFt, and AFm phases. Ettringite crystallises as relatively short needles forming compact clusters or intermixed with the C-S-H phase. The occurring C-S-H phases are mainly of type I - fibrous and type II - honeycomb.
\end{abstract}

Keywords: fly ash; fluidal combustion; hardening slurry; flood protection; embankment

\section{INTRODUCTION}

Floods are dynamic and unpredictable phenomena. They usually cause significant material damage and sometimes loss of human life. One of the methods of flood protection is constructing

\footnotetext{
${ }^{1}$ prof. D.Sc. PhD Eng. Warsaw University of Technology, Faculty of Building Services, Hydro and Environmental Engineering, Nowowiejska 20,00-653 Warsaw, e-mail: zbigniew.kledynski@is.pw.edu.pl

${ }^{2} \mathrm{PhD}$ Eng. Warsaw University of Technology, Faculty of Building Services, Hydro and Environmental Engineering, Nowowiejska 20,00-653 Warsaw, e-mail: pawel.falacinski@is.pw.edu.pl

${ }^{3} \mathrm{PhD}$ Eng. Warsaw University of Technology, Faculty of Building Services, Hydro and Environmental Engineering, Nowowiejska 20,00-653 Warsaw, e-mail: agnieszka.machowska@is.pw.edu.pl

${ }^{4}$ D.Sc. PhD. Eng., prof. AGH, AGH University of Science and Technology in Cracow, Faculty of Materials Science and Ceramics, Mickiewicz Av. 30,30-059 Cracow, e-mail: dyczek@agh.edu.pl ${ }^{5} \mathrm{PhD}$. Eng., AGH University of Science and Technology in Cracow, Faculty of Materials Science and Ceramics, Mickiewicz Av. 30, 30-059 Cracow, e-mail: 1kotwica@agh.edu.pl
} 
dikes, which prevent areas located near the river from flooding. In Poland, an area of about $1 \mathrm{mln}$ ha of agricultural terrains is protected with dikes of a combined length of about 8,500 km [12]. A great part of these dikes needs modernisation or repair. Due to limited funds for this purpose, the decision to modernise the dikes must be made after the assessment and management of flood risk [6].

In dike modernisation, technology and materials play the main role. In Poland, where coal is the dominant fossil fuel used in energy production, the applied materials may and should consist of by-products from power industry in the highest possible amount.

Fly ash produced during fluidised bed combustion of coal, conducted in low temperatures $\left(\sim 850^{\circ} \mathrm{C}\right)$ and reducing $\mathrm{SO}_{2}$ and $\mathrm{NO}_{\mathrm{x}}$ emissions, has non-spherical particles of high specific surface area with broad particle size distribution $[2,9]$. These properties result in a high water demand by this type of fly ash and limit its utilisation to landfill disposal. Research results presented in the article show the possibilities of use of this specific by-product; fly ash from circulating fluidised bed combustion (CFBC) of brown coal as the main binder's component of hardening slurry used to form cut-off walls - low permeability barriers improving the properties of objects in flood protection (dikes, earth dams) [7, 11]. The results may be used in further application of CFBC ash in flood protection.

\section{EXPERIMENTAL}

\subsection{Materials}

Hardening slurries discussed are composed of calcareous fly ash, obtained during fluidal bed combustion of brown coal, and two types of cement: CEM I 42,5 and CEM III 32,5. The slurries were modified with a small amount of sodium bentonite to provide adequate technological properties (density, viscosity, 24-hour water setting). Hardening slurry is a construction material, which should perform at compressive strength after 28 days of curing within the limits of $0.5-2.0$ $\mathrm{MPa}$, but also should be impermeable (hydraulic conductivity after 28 days of curing $<10^{-8} \mathrm{~m} / \mathrm{s}$ ). These requirements result from the specific conditions of work of cut-off walls, that is they should perform appropriate connections with the surrounding ground to work as the watertight barrier. Utilisation of CFBC fly ash as a main component (cement is just an additive) favourably influences mechanical properties and hydraulic conductivity of hardened slurries [10]. 
Fly ash used in experiments presents a high water demand, influencing strongly the workability of fresh concrete. The mentioned property, unfavourable in concrete technology, does not influence significantly the properties of hardening slurry because of high water amounts. The fly ash also presents high pozzolanic activity which makes it an interesting material from the point of view of other cement-based materials; for example cementing slurries used in drilling operations [14], as well as geotechnical works. In that case, high water demand may be seen as an advantage, when used as a density modifier in cementing slurries. Table 1 presents the chemical composition of fly ash used in experiments. As it can be seen, $\mathrm{SiO}_{2}, \mathrm{Al}_{2} \mathrm{O}_{3}$, and $\mathrm{CaO}$ are the main compounds. $\mathrm{A}$ relatively high content of calcium oxide indicates that, beside pozzolanic activity, it also performs hydraulic properties, therefore it is able to set and harden without any activators. Basic physical properties are shown in Table 2.

Table 1. Chemical composition of fly ash from fluidal combustion of brown coal

\begin{tabular}{|c|c|c|c|c|c|c|c|c|c|c|c|c|c|}
\hline \multicolumn{10}{|c|}{ compound [\%] } \\
\hline $\begin{array}{c}\mathrm{LOI} / 1 \mathrm{~h} \\
\text { at } \\
1000^{\circ} \mathrm{C}\end{array}$ & $\mathrm{SiO}_{2}$ & $\mathrm{Fe}_{2} \mathrm{O}_{3}$ & $\mathrm{Al}_{2} \mathrm{O}_{3}$ & $\mathrm{TiO}_{2}$ & $\mathrm{CaO}$ & $\mathrm{MgO}$ & $\mathrm{SO}_{3}$ & $\mathrm{Na}_{2} \mathrm{O}$ & $\mathrm{K}_{2} \mathrm{O}$ & $\mathrm{P}_{2} \mathrm{O}_{5}$ & $\mathrm{Mn}_{3} \mathrm{O}_{4}$ & $\sum$ & $\begin{array}{c}\text { uncombined } \\
\mathrm{CaO}\end{array}$ \\
\hline 2.94 & 33.02 & 5.73 & 24.29 & 1.70 & 19.94 & 1.80 & 7.60 & 1.20 & 1.40 & 0.12 & 0.04 & $\mathbf{9 9 . 8 0}$ & 7.9 \\
\hline
\end{tabular}

Table 2. Basic physical properties of fly ash used in experiments

\begin{tabular}{|c|c|c|}
\hline specific gravity $\left[\mathrm{g} / \mathrm{cm}^{3}\right]$ & specific surface BET $\left[\mathrm{cm}^{2} / \mathrm{g}\right]$ & specific surface Blaine $\left[\mathrm{cm}^{2} / \mathrm{g}\right]$ \\
\hline 2.66 & 41,500 & 7,100 \\
\hline
\end{tabular}

Pozzolanic activity was measured with the use of two methods: standard methods based on strength tests of mortars according to EN 450-1 [5] (Table 3) and the chemical method according to ASTM C379-65 [1] (Table 4). The latter considers the content of active $\mathrm{SiO}_{2}$ and $\mathrm{Al}_{2} \mathrm{O}_{3}$ within the material. Investigated fly ash exhibits very good pozzolanic activity, mainly due to the irregular shapes of its grains, and higher specific surface area. In addition, it contains highly active dehydrated clayey minerals, which are mainly responsible for pozzolanic reaction.

Table 3. Pozzolanic activity measured according to EN 450-1 [5]

\begin{tabular}{|c|c|c|}
\hline & $\begin{array}{c}\text { tensile strength } \\
{[\mathrm{MPa}]}\end{array}$ & $\begin{array}{c}\text { compressive strength } \\
{[\mathrm{MPa}]}\end{array}$ \\
\hline control mortar (CEM I 42,5) & 7.7 & 54.1 \\
\hline test mortar with fly ash $(75 \%$ OPC $+25 \%$ fly ash $)$ & 8.5 & 52.7 \\
\hline activity factor acc. EN 450-1 [\%] & 110 & 97 \\
\hline
\end{tabular}


Table 4. Pozzolanic activity measured according to ASTM C379-65 [1]

\begin{tabular}{|c|c|c|}
\hline \multicolumn{3}{|c|}{ compound $[\%]$} \\
\hline $\mathrm{SiO}_{2}$ active & $\mathrm{Al}_{2} \mathrm{O}_{3}$ active & $\mathbf{S i O}_{2}$ active $+\mathbf{A l}_{2} \mathbf{O}_{3}$ active \\
\hline 12.99 & 9.18 & $\mathbf{2 2 . 1 7}$ \\
\hline
\end{tabular}

\subsection{Preparation Of SAMPLES}

Samples (three for each formulae and test) were prepared with mechanical mixing of dry components with $+18 \pm 2^{\circ} \mathrm{C}$ tap water according to three formulae (Table 5). Samples for strength tests were prepared in steel cylinder moulds measuring $8 \mathrm{~cm}$ in both diameter and height. Samples for hydraulic conductivity tests were prepared in PVC cylinder moulds measuring $7.5 \mathrm{~cm}$ in diameter and $8 \mathrm{~cm}$ in height [8]. After setting, the samples were put in basins with $+18 \pm 2{ }^{\circ} \mathrm{C}$ water.

Table 5. Dosage of components of hardening slurry

\begin{tabular}{|c|c|c|c|c|c|c|}
\hline Sample: & 1 & 2 & 3 & 4 & 5 & 6 \\
\hline Water [kg] & 1000 & 1000 & 1000 & 1000 & 1000 & 1000 \\
\hline Bentonite [kg] & 40 & 40 & 40 & 40 & 40 & 40 \\
\hline CEM I 42,5 [kg] & 160 & 170 & 180 & - & - & - \\
\hline CEM III 32,5[kg] & - & - & - & 160 & 170 & 180 \\
\hline Fly ash [kg] & 300 & 380 & 450 & 300 & 380 & 450 \\
\hline
\end{tabular}

\subsection{TEST METHODS}

Laboratory analyses covered the following tests:

- compressive strength tests were conducted accordingly to EN 12390-3 [4]. Samples were compressed with velocity equal to $0.05 \mathrm{MPa} / \mathrm{s}$.

- hydraulic conductivity tests were conducted in a specialized apparatus [8].

- phase composition of samples was determined using XRD. Samples of appropriate size were crushed with a mortar and a pestle, dried in a desiccator under high vacuum and grounded with agate mortar and pestle until the entire sample passed through a $63 \mu \mathrm{m}$ sieve. Then samples were subjected to XRD analysis using the Philips PW 1130 apparatus with a $\mathrm{Cu}$ cathode, beam parameters were set to $16 \mathrm{~mA}$ and $35 \mathrm{kV}$, step was $0.05^{\circ}$ theta and acquisition time was $3 \mathrm{~s} / \mathrm{step}$.

- hydrated slurries were observed using the FEI Nova NanoSEM 200 scanning electron microscope. Samples were not dried prior to observation. Small pieces of hardened slurries were taken from the bars and placed on the holder, transferred to the coater, and covered with a 
thin carbon layer to avoid charging, then observed in low vacuum mode at $60 \mathrm{~Pa}$ water vapour pressure.

- for mercury porosimetry, a Carlo Erba 2000 porosimeter with low- and high-pressure equipment was used. Samples were investigated up to $2000 \mathrm{~atm}$. Samples for porosimetry were split off, then dried in a vacuum desiccator to constant mass.

\section{RESULTS AND DISCUSSION}

\subsection{COMPRESSIVE STRENGTH AND HYDRAULIC CONDUCTIVITY}

Each formulation of investigated hardened slurries shows an increase of compressive strength at the time of curing (Table 6), which indicates the progress of the hydration process of the fly ashcement binder. Samples consisting of more fly ash (formulae 2 and 5: FA/C=2.18; formulae 3 and 6: $\mathrm{FA} / \mathrm{C}=2.45$ ) perform at a higher value of strength than samples consisting of more cement. The value of compressive strength of the $3 / 28$ formula is about $81 \%$ higher than the strength of the $1 / 28$ one.

Table 6. Compressive strength and hydraulic conductivity of slurries after 28 and 90 days of curing

\begin{tabular}{|c|c|c|c|c|c|c|c|}
\hline \multicolumn{2}{|c|}{ Sample } & 1 & 2 & 3 & 4 & 5 & 6 \\
\hline $\mathrm{f}_{\mathrm{c}}$, & 28 days & $1,37( \pm 10 \%)$ & $1,90( \pm 13 \%)$ & $2,43( \pm 17 \%)$ & $0,84( \pm 17 \%)$ & $1,24( \pm 11 \%)$ & $2,01( \pm 21 \%)$ \\
\cline { 2 - 8 } $\mathrm{MPa}$ & 90 days & $1,59( \pm 9 \%)$ & $2,01( \pm 16 \%)$ & $3,01( \pm 2 \%)$ & $0,99( \pm 4 \%)$ & $1,69( \pm 15 \%)$ & $2,43( \pm 2 \%)$ \\
\hline & \multirow{2}{*}{28 days } & $\begin{array}{c}2,86 \cdot 10^{-8} \\
( \pm 37 \%)\end{array}$ & $\begin{array}{c}1,09 \cdot 10^{-8} \\
( \pm 8 \%)\end{array}$ & $\begin{array}{c}3,34 \cdot 10^{-8} \\
( \pm 53 \%)\end{array}$ & $\begin{array}{c}3,50 \cdot 10^{-8} \\
( \pm 13 \%)\end{array}$ & $\begin{array}{c}3,27 \cdot 10^{-8} \\
( \pm 15 \%)\end{array}$ & $\begin{array}{c}1,23 \cdot 10^{-8} \\
( \pm 17 \%)\end{array}$ \\
$\mathrm{k}_{10}$, & $\begin{array}{c}3,43 \cdot 10^{-8} \\
\mathrm{~m} / \mathrm{s}\end{array}$ & \multirow{2}{*}{$\begin{array}{c}0,92 \cdot 10^{-8} \\
( \pm 24 \%)\end{array}$} & $\begin{array}{c}0,89 \cdot 10^{-8} \\
( \pm 11 \%)\end{array}$ & $\begin{array}{c}5,78 \cdot 10^{-8} \\
( \pm 3 \%)\end{array}$ & $\begin{array}{c}4,35 \cdot 10^{-8} \\
( \pm 9 \%)\end{array}$ & $\begin{array}{c}1,49 \cdot 10^{-8} \\
( \pm 10 \%)\end{array}$ \\
\hline
\end{tabular}

Analysing the samples with an addition of CEM III 32,5, it can be observed that compressive strength of the $6 / 28$ formula is $135 \%$ higher than the strength of the $4 / 28$ one. In addition, a rise of the strength value between 28 and 90 days of curing can be stated. Samples 3 and $6(\mathrm{FA} / \mathrm{C}=2.45)$ show a rise of the compressive strength value of about $22 \%$, and samples 1 and $4(\mathrm{FA} / \mathrm{C}=1.81)$ of about $18 \%$. In the case of samples 2 and $5(\mathrm{FA} / \mathrm{C}=2.18)$ the rise of strength value is respectively about $5 \%$ and $36 \%$. This indicates high hydraulic and pozzolanic activity of fly ash applied during the research.

All samples of hardened slurry show an adequate level of hydraulic conductivity after 28 days of curing (about $10^{-8} \mathrm{~m} / \mathrm{s}$ ). Changes of conductivity after up to 90 days of hydration do not influence significantly the coefficient of hydraulic conductivity, considering measurement uncertainties. An 
increase of the material's water tightness may be observed together with the increase of fly ash amounts in samples. It is shown that the progressive process of hydration results in the creation of hydrated calcium silicates, promoting an increase in strength and water tightness of fly ash-cement composites. The growth of hydraulic conductivity values of samples is most probably the result of that measurement's uncertainties, because it is not confirmed by porosity tests (see p. 3.3). The results of porosity tests show a decrease of the threshold pore diameter in time, which indicates an increase of the material's tightness.

\subsection{X-RAY DIFFRACTION OF CEMENT-ASH SLURRIES}

Figs. 1 and 2 show XRD patterns of slurries containing CEM I (samples no. $1 \div 3$ ), and CEM

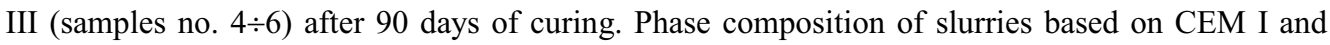
CEM III is similar. In both cases, the main phase compounds of pastes after 90 days of hydration were: ettringite, hexagonal hydrated calcium aluminates (AFm), mainly carboaluminate, quartz, and C-S-H phase. Slurries with CEM I exhibit higher amounts of AFm phases comparing to CEM III.

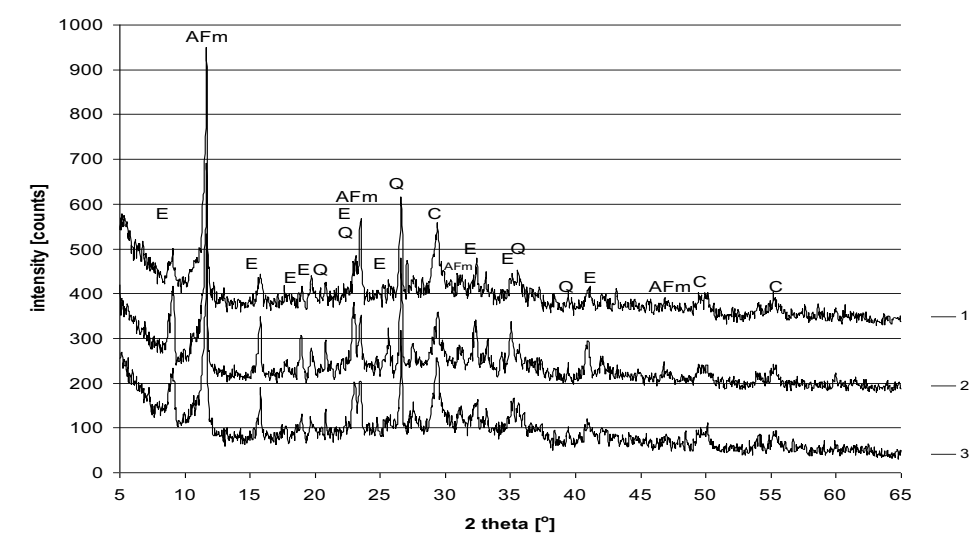

Fig. 1. XRD patterns of CEM I based slurries after 90 days of curing. $\mathrm{E}$ - ettringite, AFm - hexagonal hydrated calcium aluminates, Q - quartz, C - C-S-H phase 


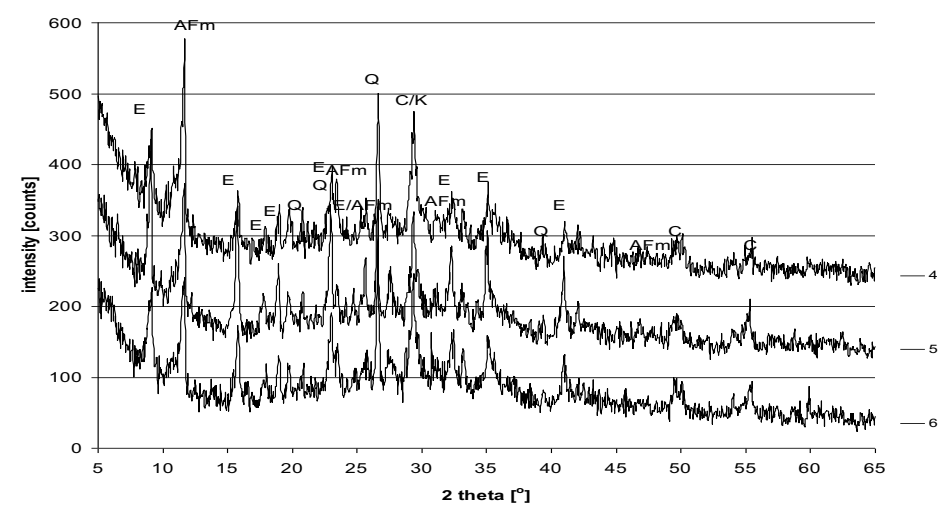

Fig. 2. XRD patterns of CEM III based slurries after 90 days of curing. E - ettringite, AFm - hexagonal hydrated calcium aluminates, Q - quartz, C - C-S-H phase, K - calcite

In Table 7 relative intensities of main XRD peaks of AFm and ettringite are compared. The results show that CEM I promotes formation of the AFm phase and high water-to-binder ratios leads to high $\mathrm{AFm} / \mathrm{AFt}$ peak intensity ratios. In both slurries, there is a considerable amount of the C-S-H phase present in hydrated slurries. Moreover, no peaks of alite were found. This means that the rate of hydration of the cement is high, close to $100 \%$. It is possibly due to the relatively high water-to-cement ratio of the slurries. Quartz present in hardened slurries originates from fly ash, and since is not reactive it remains unchanged.

Table 7. Comparison of XRD peak-relative intensities $\left(\mathrm{I}_{\mathrm{AFM}} / \mathrm{I}_{\mathrm{Etr}}\right)$

\begin{tabular}{|c|c|c|c|c|c|c|}
\hline Sample & 1 & 2 & 3 & 4 & 5 & 6 \\
\hline $\mathrm{I}_{\mathrm{AFM}} / \mathrm{I}_{\mathrm{Ettr}}$ & 9.2 & 4.1 & 4.8 & 3.5 & 1.7 & 1.6 \\
\hline
\end{tabular}

\subsection{Porosity}

Among parameters obtained during porosimetric testing, a threshold diameter was used as the most valuable parameter describing pore structure. The most important feature of investigated slurries is their low hydraulic conductivity. The work of Illston et al. showed [13] that hydraulic conductivity of pastes is connected with the diameter of continuous capillary pores. The threshold diameter is a parameter which refers to the continuity of the capillary pore system. The values of the threshold diameter, between 28 and 90 days, decrease between 2 and 3.5 times. Slurries made of CEM III are characterized by smaller threshold diameters. This observation is consistent with data 
on porosity of typical cement pastes made with CEM I and CEM III. It can be observed that the higher water-to-solid ratio, the higher the threshold diameter value.

Fig. 3 presents the relationship between the MIP threshold diameter and the water-to-binder (cement + fly ash) ratio. In general, slurries made with CEM III exhibit lower values of the threshold diameter for the same water-to-binder ratio, compared to the CEM I samples. The differences are smaller in the range of low water-to-binder ratios, and increase for higher values of water-to-binder ratios. This means that CEM III is a good solution for cement-based fly ash-rich slurries for flood protecting dikes. Slurries based on CEM III result in finer pore structure and are less sensitive to water/binder fluctuations comparing to CEM I based slurries. It is a favourable feature, since some mistakes always happen on construction sites.

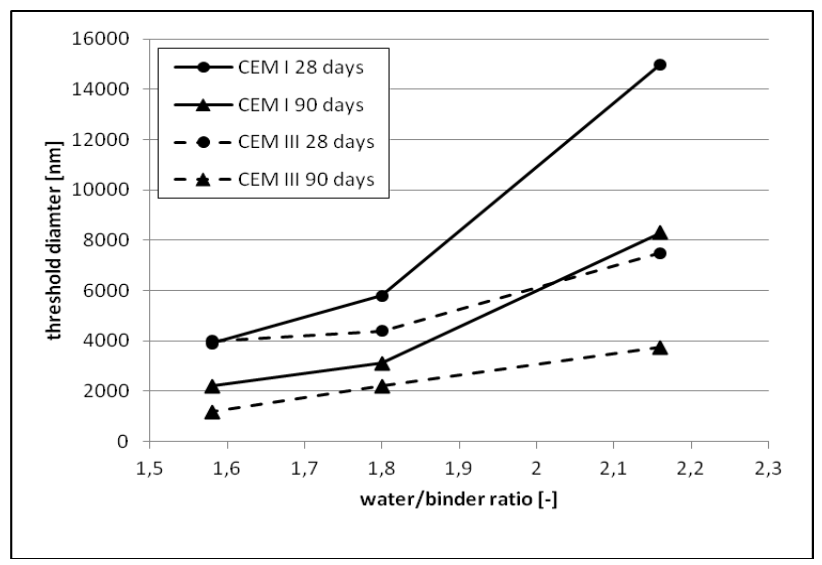

Fig. 3. Threshold diameter plotted vs. water-to-binder ratios of investigated slurries

\subsection{SEM ANALYSIS}

Microstructure of fractured samples was performed after 28 and 90 days of curing. In the case of both CEM I as well as CEM III slurries, observations revealed presence of well-crystallised large hexagonal hydrated calcium aluminates, mainly sulfur-bearing ones, which are dispersed throughout the matrix as individual crystals or crystals agglomerates. 

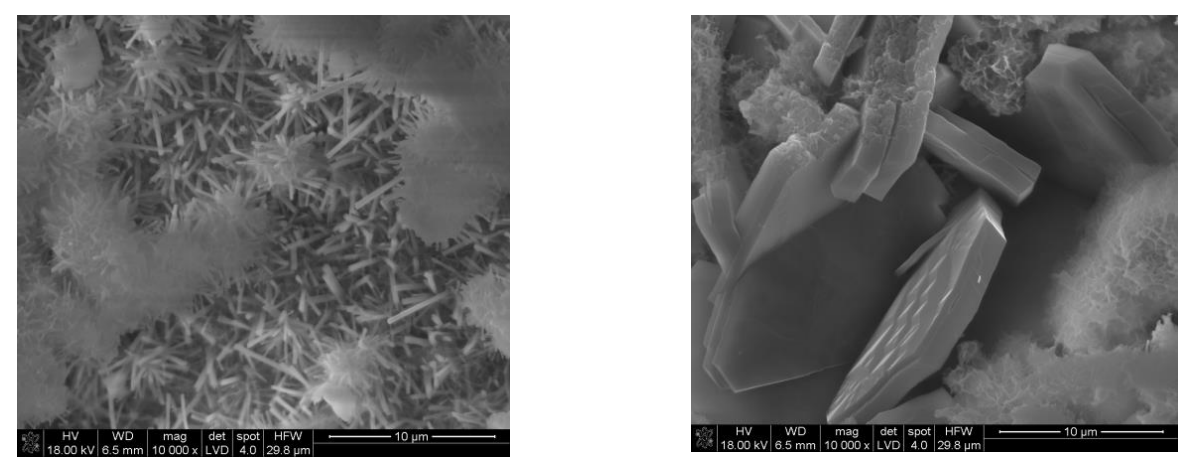

Fig. 4. Ettringite crystals (left) and hexagonal crystals of hydrated calcium aluminates (right) in sample 4

In Fig. 4, crystals of AFm phases in sample 4 are presented. In both samples, ettringite crystals were also found. Ettringite crystallizes in the form of relatively short needles forming either ettringite compacted clusters (Fig. 4) or intermixed with the C-S-H phase. The C-S-H phases occurring in hardened samples are mainly of type I (fibrous) and II (honeycomb) according to the Diamond [3]. The microstructure of investigated slurries consists mainly of the C-S-H phase precipitated on starting fly ash grains, binding them together. It is granular in nature, due to the relatively high water-to-binder ratios. CEM III based slurries exhibit finer microstructure composed of smaller elements than the CEM I slurries. This observation is consistent with MIP results.

\section{SUMMARY}

An increase of compressive strength in time of curing is observed concerning all formulas of slurry. Samples with higher amount of CFBC fly ash from brown coal present higher values of strength. CEM III based slurries with large amounts of CFBC fly ash are valuable materials for flood protecting dikes, exhibiting lower pore diameter (which is less sensitive to water-to-binder ratio fluctuations) and a finer microstructure composed of smaller elements, comparing to the CEM I based slurries. Use of CEM I in slurries containing large amounts of fly ash promotes formation of AFm phases, while use of CEM III promotes formation of AFt phases.

Investigations were carried out as part of the IniTech programme No. ZPB/61/65832/IT2/10. 


\section{REFERENCES}

1. ASTM C379-65 Specification for fly ash for use as a pozzolanic material with lime.

2. M. Brandt (ed.), "Utilization of fly ashes from circulating fluidal bed combustion in construction concrete", Pol Acad of Sci Com of Civil Eng, Poland, 2010 (in Polish).

3. S. Diamond, "Cement pastes microstructure - an overview at several levels. Proc. of a Conf. on Hydr Cem Paste: their structure and properties", Sheffield, 1976.

4. EN 12390-3: Testing hardened concrete. Compressive strength of test specimens.

5. EN 450-1: Fly ash for concrete. Definition, specifications and conformity criteria.

6. EU Floods Directive 2007/60/EC on the assessment and management of flood risks entered into force on 6th November 2007.

7. J. Evans, A. Dawson, S. Opdyke, "Slurry walls for groundwater control: a comparison of UK and US practice", ASCE/PENNDOT Central PA Geotechnical Conf., 2002.

8. P. Falaciński, Z. Kledyński,.” Influence of aggressive liquids on hydraulic conductivity of hardening slurries with the addition of different fluidal fly ashes", Environmental Engineering, pp 295-300, 2007.

9. Z. Giergiczny, "Role of calcarous and silicious fly ash in shaping the properties of contemporary binders and cement composites", Mon. of Cracow University of Technology, Cracow, 2006 (in Polish).

10. Z. Kledyński, A. Machowska, "Hardening slurries with ground granulated blast furnace slag activated with fluidal fly ash from lignite combustion”, Przemysł Chemiczny 92 (4), pp 490-497, 2013.

11. Z. Kledyński, L. Rafalski, "Hardening slurries", Polish Academy of Sciences, Comitee of Civil Engineering, Warsaw, 2009 (in Polish).

12. W. Mioduszewski, "Flood protection”, Wiadomości Melioracyjne i Łąkarskie, Tom LIII: No 4, 2010 (in Polish).

13. B.K. Nyame, J.M. Illston, 7th ICCC Paris, III: VI-181. Paris, 1980.

14. S. Stryczek, W. Brylicki, J. Małolepszy, A. Gonet, R. Wiśniowski, Ł. Kotwica, "Potential use of fly ash from fluidal combustion of brown coal in cementing slurries for drilling and geotechnical works", Archives of Mining Sciences, 54, pp 775-786, 2009. 


\section{LIST OF FIGURES AND TABLES}

Fig. 1. XRD patterns of CEM I based slurries after 90 days of curing, E - ettringite, AFm - hexagonal hydrated calcium aluminates, $\mathrm{Q}$ - quartz, $\mathrm{C}-\mathrm{C}-\mathrm{S}-\mathrm{H}$ phase

Rys. 1. Dyfraktogramy rentgenowskie zawiesin z cementem portlandzkim po 90 dniach dojrzewania, E etryngit, AFm - heksagonalne uwodnione gliniany wapnia, Q - kwarc, C - faza C-S-H

Fig. 2. XRD patterns of CEM III based slurries after 90 days of curing, E - ettringite, AFm - hexagonal hydrated calcium aluminates, $\mathrm{Q}$ - quartz, $\mathrm{C}-\mathrm{C}-\mathrm{S}-\mathrm{H}$ phase, $\mathrm{K}$ - calcite

Rys. 2. Dyfraktogramy rentgenowskie zawiesin z cementem hutniczym po 90 dniach dojrzewania, E etryngit, AFm - heksagonalne uwodnione gliniany wapnia, Q - kwarc, C - faza C-S-H, K - kalcyt

Fig. 3. Threshold diameter plotted vs. water-to-binder ratio of investigated slurries

Rys. 3. Średnica progowa w funkcji wskaźnika woda/spoiwo dla badanych zawiesin

Fig. 4. Ettringite crystals (left) and hexagonal crystals of hydrated calcium aluminates (right) in sample 4

Rys. 4. Kryształy etryngitu (po lewej) i heksagonalne kryształy uwodnionych glinianów wapnia (po prawej) W próbce $\mathrm{nr} 4$

Fig. 5. Comparison of microstructure of fractured samples of CEM I (left) and CEM III (right) based slurries

Rys. 5. Porównanie mikrostruktury próbek zawiesiny wykonanych z cementem portlandzkim (po lewej) i cementem hutniczym (po prawej)

Tab. 1. Chemical composition of fly ash from fluidal combustion of brown coal

Tab. 1. Skład chemiczny popiołu lotnego z fluidalnego spalania węgla brunatnego

Tab. 2. Basic physical properties of fly ash used in experiments

Tab. 2. Podstawowe właściwości fizyczne popiołu lotnego wykorzystanego w badaniach

Tab. 3. Pozzolanic activity measured according to EN 450-1

Tab. 3.Aktywność pucolanowa wyznaczona zgodnie z EN 450-1

Tab. 4. Pozzolanic activity measured according to ASTM C379-65

Tab. 4. Aktywność pucolanowa wyznaczona zgodnie z ASTM C379-65

Tab. 5. Percentage dosage of components per $1 \mathrm{~m}^{3}$ of hardening slurry

Tab. 5. Procentowe dozowanie składników na $1 \mathrm{~m}^{3}$ zawiesiny twardniejącej

Tab. 6. Compressive strength and hydraulic conductivity of slurries after 28 and 90 days of curing

Tab. 6. Wytrzymałość na ściskanie i przewodność hydrauliczna zawiesin po 28 i 90 dniach dojrzewania

Tab. 7. Comparison of XRD peaks relative intensities $\left(\mathrm{I}_{\mathrm{AFm}} / \mathrm{I}_{\mathrm{Ettr}}\right)$

Tab. 7. Porównanie refleksów względnych wartości intensywności $\left(\mathrm{I}_{\mathrm{AFm}} / \mathrm{I}_{\mathrm{Etrt}}\right)$ 


\section{WYKORZYSTANIE POPIOLU LOTNEGO ZE SPALANIA W ZLOŻU Z CYRKULACYJNĄ WARSTWĄ FLUIDALNĄ W ZAWIESINACH TWARDNIEJĄCYCH STOSOWANYCH W NAPRAWACH WALÓW PRZECIWPOWODZIOWYCH}

Słowa kluczowe: popiół lotny, spalanie fluidalne, zawiesina twardniejąca, ochrona przeciwpowodziowa, wał przeciwpowodziowy

\section{STRESZCZENIE}

W artykule przedstawiono wyniki badań właściwości mechanicznych, filtracyjnych oraz składu fazowego i mikrostruktury zawiesin twardniejących wykonanych z udziałem popiołu lotnego z fluidalnego spalania węgla brunatnego po 28 i 90 dniach dojrzewania. Ten rodzaj popiołu lotnego wykazuje się wysoką wodożądnością, co ogranicza możliwość jego wykorzystania w technologii betonu. Natomiast jego dodatek nie wpływa na właściwości zawiesiny twardniejącej ze względu na dużą zawartość wody. Zawiesiny wykonano wg trzech receptur w dwóch wariantach (po trzy próbki na każdą recepturę, termin i rodzaj badania), w których popiół lotny był głównym składnikiem spoiwa, a do niego dodano odpowiednio cement portlandzki CEM I 42,5 (próbki 1-3) i cement hutniczy CEM III 32,5 (próbki 4-6). Proporcje popiołu do cementu były następujące: 1,81 (próbki 1 i 4), 2,18 (próbki 2 i 5), 2,45 (próbki 3 i 6).

W wykorzystanym popiele lotnym głównymi związkami, pod względem składu chemicznego, są $\mathrm{SiO}_{2}, \mathrm{Al}_{2} \mathrm{O}_{3}$ i $\mathrm{CaO}$. Względnie wysoka zawartość tlenku wapnia wpływa na aktywność pucolanową i własności hydrauliczne badanego popiołu. Aktywność pucolanowa popiołu została określona z wykorzystaniem dwóch metod badawczych: zgodnie z normą EN 450-1 poprzez określenie wskaźnika aktywności na podstawie badań wytrzymałości na ściskanie i zginanie beleczek wykonanych z udziałem popiołu, a także wg normy amerykańskiej ASTM C379-65 poprzez wykonanie badań chemicznych popiołu. Na wysoką aktywność pucolanową zastosowanego popiołu ma wpływ także wysoka powierzchnia właściwa ziaren (metoda Blaine'a: $7,100 \mathrm{~cm}^{2} / \mathrm{g}$, met. BET: $41,500 \mathrm{~cm}^{2} / \mathrm{g}$ ), ich nieregularny kształt oraz zawartość wysokoaktywnych uwodnionych minerałów ilastych.

Badania mechaniczne zawiesin wykonano zgodnie z normą EN 12390-3. Badania przewodności hydraulicznej wykonano w specjalnie do tego celu wytworzonej aparaturze opisanej szczegółowo w publikacji [8]. Skład fazowy określono metodą dyfraktometrii rentgenowskiej w aparacie Philips PW 1130 z katodą $\mathrm{Cu}\left(16 \mathrm{~mA}, 35 \mathrm{kV}, 0,5^{\circ} \theta\right.$, $3 \mathrm{~s} /$ krok). Mikrostrukturę zawiesin stwardniałych zobrazowano z użyciem skaningowego mikroskopu elektronowego FEI Nova NanoSEM 200 (obserwacja w niskiej próżni 60 Pa), a wielkości i rozkład porów określono metodą porozymetrii rtęciowej w aparacie Carbo Erba 2000 (ciśnienie do 2000 atm).

Wykonane badania wytrzymałości na ściskanie zawiesin w dwóch terminach dojrzewania wykazały postępujący proces hydratacji spoiwa. Ponadto próbki z większą zawartością popiołu lotnego wykazują wyższą wytrzymałość mechaniczną w porównaniu do próbek z jego mniejszą zawartością. Wszystkie próbki zawiesiny twardniejącej (z cementem portlandzkim i cementem hutniczym) uzyskały wymaganą wartość przepuszczalności hydraulicznej po 28 dniach dojrzewania $\left(<10^{-8} \mathrm{~m} / \mathrm{s}\right)$. Zaobserwowano wzrost szczelności próbek zawiesiny wraz ze wzrostem ilości popiołu w ich składzie. Wzrost wartości przepuszczalności hydraulicznej kilku próbek wynika najprawdopodobniej z niepewności pomiarowych, gdyż nie został on potwierdzony wzrostem porowatości zawiesiny.

Skład fazowy zawiesin po 90 dniach dojrzewania wykonanych z udziałem cementu portlandzkiego i hutniczego jest podobny: główne fazy to etryngit, heksagonalne kryształy uwodnionych glinianów wapnia (AFm), kwarc i uwodnione krzemiany wapnia (faza C-S-H). Zawiesiny wykonane z cementem portlandzkim zawierają więcej fazy AFm niż AFt 
w porównaniu do zawiesin wykonanych z cementem hutniczym. Ponadto im większy jest wskaźnik woda/spoiwo w zawiesinie tym większy wskaźnik intensywności refleksów AFm/AFt. W zawiesinach nie zaobserwowano obecności alitu, co oznacza wysoki stopień przereagowania cementu (zbliżony do 100\%) i wynika najprawdopodobniej z wysokiej wartości wskaźnika woda/cement w zawiesinach.

W celu określenia struktury porów zawiesiny stwardniałej wykorzystano metodę porozymetrii rtęciowej. W badaniach określono tzw. średnicę progową - parametr charakteryzujący system porów kapilarnych w zawiesinie. Stwierdzono, że w miarę upływu czasu dojrzewania zawiesiny średnica progowa maleje od dwóch do trzech i pół razy, co jest potwierdzeniem postępującego procesu hydratacji spoiwa popiołowo-cementowego. Zaobserwowano, że zawiesiny wykonane z dodatkiem cementu hutniczego charakteryzują się niższą wartością średnicy progowej, a w miarę obniżenia wskaźnika woda/spoiwo następuje również obniżenie wartości średnicy progowej. Ponadto zawiesiny wykonane z cementem hutniczym wykazują się drobniejszymi porami i mniejszą wrażliwością na zmiany wskaźnika woda/spoiwo w porównaniu do zawiesin wykonanych z cementem portlandzkim.

Mikrostruktura zawiesiny po 28 i 90 dniach dojrzewania charakteryzuje się głównie zawartością fazy uwodnionych krzemianów wapnia (C-S-H) uformowanej na ziarnach popiołu oraz etryngitu wykształconego w fazie C-S-H w postaci pojedynczych igieł lub skupisk igieł. Faza C-S-H występuje głównie w formie włóknistej (typ I) i w formie plastra miodu (typ II) [3]. Ponadto zaobserwowano duże heksagonalne kryształy uwodnionych glinianów wapnia w postaci pojedynczych kryształów lub aglomeratów osadzonych w matrycy cementowej. Mikrostruktura zawiesin jest ziarnista, co wynika z wysokiego wskaźnika wodno/spoiwowego. W przypadku zawiesin wykonanych z udziałem cementu hutniczego jest ona drobniejsza i składa się z mniejszych form.
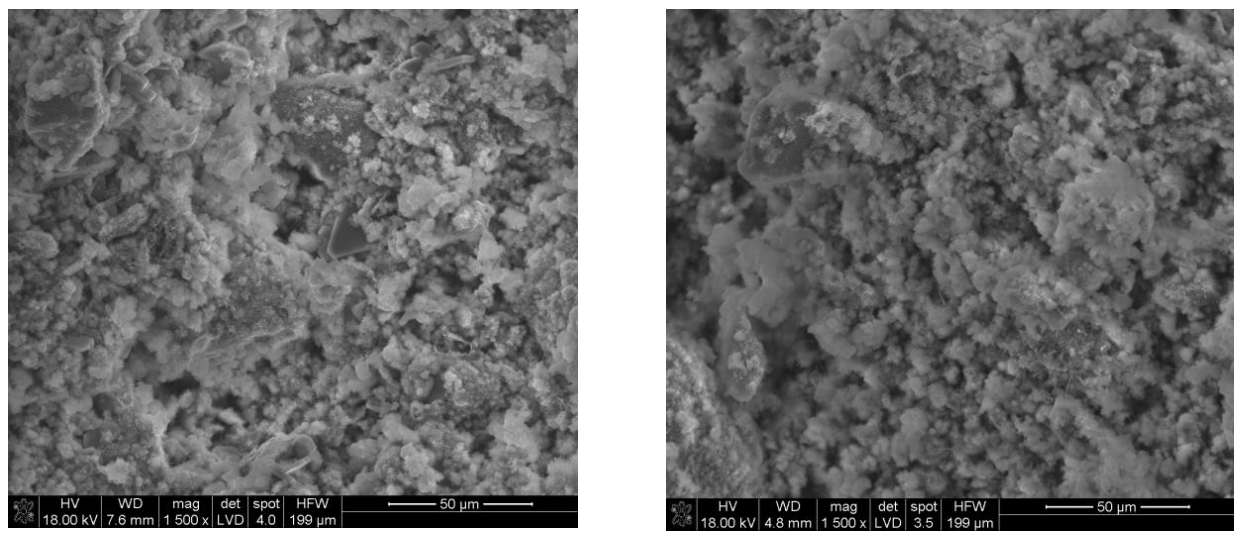

Rys. 5. Porównanie mikrostruktury próbek zawiesiny wykonanych z cementem portlandzkim (po lewej) i cementem hutniczym (po prawej) 
